\title{
Riparian vegetation metrics as tools for guiding ecological restoration in riverscapes
}

\author{
F. Constança Aguiar ${ }^{(1)}, M$. Rosário Fernandes $^{(1)}$, and M. Teresa Ferreira ${ }^{(1)}$ \\ Received December 3, 2010 \\ Revised May 13, 2011 \\ Accepted August 5, 2011
}

\section{ABSTRACT}

Key-words: Riparian woods are frequently fragmented and degraded, mainly as a

GIS

applications, ecological condition, indices, landscape metrics, riparian woods consequence of land-cover related stresses, water diversion, regulation and invasive species. The need to enhance these systems towards their natural functioning has motivated numerous restoration efforts. However, river managers still need guidance on how to allocate scarce restoration resources, and to monitor and report the effectiveness of the restoration programmes. For this, the present work proposes a stepwise methodological procedure over spatial scales, using quantitative descriptors (metrics) of the ecological condition of the riparian vegetation. This evaluation is based on the composition and cover of plant assemblages, species attributes, and spatial patterns, which can reflect the deviation of the structure and condition of the riparian zone from the near-natural state to an impaired situation. Landscape metrics obtained from high spatial resolution imagery are used for the evaluation of the spatial features of the riparian zone, followed by the calculation of a riparian multimetric index, based on field observations. The integration of multi-spatial scale information provided by landscape metrics and biological metrics is essential and recommended for decision support of end-users and to evaluate the success of restoration measures.

\section{RÉSUMÉ}

Descripteurs de la végétation rivulaire comme guide de la restauration écologique au sein des paysages de cours d'eau

Mots-clés :

SIG, état écologique, indices, descripteurs du paysage, bois rivulaires
La dégradation et la fragmentation fréquentes des bois rivulaires sont principalement dues à des pressions d'usage du sol, à des modes de gestions des écoulements de l'eau et à la concurrence par des espèces invasives. C'est ce besoin de retour à des fonctionnements plus proches des conditions naturelles qui a motivé nombre d'efforts de restauration. Toutefois les gestionnaires de cours d'eau sont demandeurs d'outils d'évaluation des programmes de restauration et des manières de gérer des ressources qui se raréfient. Pour cela, notre travail propose une méthode hiérarchisée à des échelles spatiales variées, par des descripteurs quantitatifs (métriques) de l'état écologique de la végétation riparienne. Cette évaluation se fait à partir de la composition et du recouvrement des assemblages de plantes, des exigences spécifiques, et de leur répartition spatiale. Cette répartition spatiale est le reflet de l'écart de la structure et de l'état des 
berges, d'un état de référence quasi-naturel à une situation dégradée. Les métriques paysagères obtenues à partir d'une imagerie spatiale à haute résolution sont utilisées pour évaluer les particularités spatiales des berges, puis pour le calcul d'un indice rivulaire multifactoriel basé sur des observations de terrain. L'intégration d'une information spatiale multi-scalaire renseignée par des descripteurs du paysage est essentielle et recommandée comme support de décision pour les gestionnaires et pour évaluer le succès d'actions de restauration.

\section{INTRODUCTION}

Rivers and riparian areas of Iberia, Southwestern Europe, have been subjected to huge human disturbances for millennia, such as water diversion, regulation, land-use, afforestation, grazing, physical interventions on riverbanks, amongst others (Ferreira et al., 2005; Hooke, 2006; von Schiller et al., 2008). These manifold types of pressures often result in biodiversity and habitat loss, and invasion by alien plant species, as well as an overall degradation of the riparian ecosystem (Aguiar et al., 2001; Allan, 2004; Aguiar and Ferreira, 2005). Numerous functions and ecosystem services are attributed to these areas, and have been addressed in detail by Naiman et al. (2005). The riparian woods are settled in a transition area between the terrestrial and aquatic areas, and function as ecotone systems within the landscape, with extreme importance for the lateral, longitudinal and vertical flows of energy and biomass (Naiman and Décamps, 1997). Riparian woods have a linear structure and frequently present a transversal zonation of species assemblages, as a result of the interplay of water availability and species requirements. The fragmentation and loss of zonation and strata complexity of riparian areas reduces the efficiency of the functioning of these ecosystems (Schuft et al., 1999; Lake et al., 2007), including their use as an ecological corridor, as habitat and refuge and increases the susceptibility to invasion and the terrestrialization of the riparian zone. Though the fragmental patterns of vegetation have been widely used to assess the degradation of these ecosystems (Ward et al., 2003), other features should also be taken into account (González-del-Tánago and García-Jalón, 2006). The lateral dimension (riparian width), the dimension, spatial configuration and spatial distribution of the riparian patches (riparian structure), and the floristic components (riparian composition) are essential to characterize and evaluate the condition of the riparian zones (Moser et al., 2000). Riparian areas are composed by patches, i.e. homogenous areas with different dynamics that can be distinguish within the riparian zone (Apan et al., 2002). The concept of landscape structure and riparian patches has been only applied recently (Apan et al., 2002) and few studies have been published (Fernandes et al., 2011). Remote sensing has been used to map and characterize riparian vegetation features such as the percentage of canopy cover, canopy continuity and tree clearing (Aguiar and Ferreira, 2005; Johansen and Phinn, 2006), buffer capacity (Ivits et al. , 2009), width (Hyatt et al., 2004) and strata complexity (Johansen et al., 2007). However, the coarse spatial resolution of the images that have been used and the mismatch between the riparian buffer considered and the real riparian area lead to errors in the estimation of these parameters (Schuft et al., 1999; Congalton et al., 2002; Yang, 2007).

Landscape metrics, numeric descriptors that quantify patch configuration and the spatial relationships among patches, can be used to characterize the structure of riparian vegetation and help to make informed decisions on restoration planning, such as revegetating the riparian zones (Apan et al., 2002). These metrics can be related with general ecological processes and dynamics of riparian zones and express the ecological condition of riparian woods (Table I). The spatial patterns of vegetation should include the analysis of the fragmentation - the lack of longitudinal connectivity - and the dimension, the spatial heterogeneity and structural complexity of patches (Forman and Godron, 1981; Forman, 1995). For instance, fragmental patterns indicated by mean proximity index and mean nearest-neighbor distance, usually express poor ecological conditions (Schuft et al., 1999); meandering shapes of riparian patches identified by the mean shape index indicate large boundaries with the adjacent lands, expressing high lateral connectivity (Forman, 1995). 


\section{Table I}

List of landscape metrics per structural categories and acronyms. General ecological processes related with the landscape metrics, and applications to the analysis of the spatial patterns of riparian vegetation (based mainly on Forman and Godron, 1981; Forman, 1995 and Apan et al., 2002).

\section{Tableau 1}

Liste and acronymes des variables descriptives du paysage par catégorie de structure. Processus écologiques généraux selon des descripteurs du paysage et application à l'analyse spatiale et structurelle de la végétation rivulaire (d'après principalement Forman and Godron, 1981 ; Forman, 1995 et Apan et al., 2002).

\begin{tabular}{|c|c|c|c|c|}
\hline \begin{tabular}{|l} 
Structural \\
category
\end{tabular} & $\begin{array}{l}\text { Landscape } \\
\text { metrics }\end{array}$ & Acronym & $\begin{array}{l}\text { Related vegetational } \\
\text { ecological processes }\end{array}$ & Spatial patterns \\
\hline \multirow[t]{3}{*}{ Area/density } & $\begin{array}{l}\text { Number of } \\
\text { patches }\end{array}$ & NP & \multirow{3}{*}{$\begin{array}{c}\text { Productivity, } \\
\text { biogeochemical } \\
\text { cycling, biodiversity }\end{array}$} & \multirow{3}{*}{$\begin{array}{c}\text { Fragmentation and } \\
\text { structural } \\
\text { heterogeneity }\end{array}$} \\
\hline & Mean patch size & MPS & & \\
\hline & $\begin{array}{l}\text { Patch size } \\
\text { coefficient of } \\
\text { variation }\end{array}$ & PSCV & & \\
\hline Shape & $\begin{array}{l}\text { Mean shape } \\
\text { index }\end{array}$ & $\mathrm{MSI}$ & \multirow[t]{2}{*}{$\begin{array}{l}\text { Edge effects, lateral } \\
\text { connectivity }\end{array}$} & \multirow{2}{*}{$\begin{array}{l}\text { Spatial configuration } \\
\text { and complexity of } \\
\text { riparian patches }\end{array}$} \\
\hline Area/edge & $\begin{array}{c}\text { Mean fractal } \\
\text { dimension index }\end{array}$ & MPFD & & \\
\hline \multirow[t]{2}{*}{$\begin{array}{l}\text { Isolation/ } \\
\text { proximity }\end{array}$} & $\begin{array}{c}\text { Mean nearest- } \\
\text { neighbor distance }\end{array}$ & MNN & \multirow{2}{*}{$\begin{array}{l}\text { Neighborhood effects, } \\
\text { habitat and refugia } \\
\text { discontinuity, } \\
\text { ecological and energy } \\
\text { flows }\end{array}$} & \multirow[t]{2}{*}{$\begin{array}{l}\text { Isolation of riparian } \\
\text { patches, } \\
\text { interconnectivity }\end{array}$} \\
\hline & $\begin{array}{l}\text { Mean proximity } \\
\text { index }\end{array}$ & MPI & & \\
\hline \begin{tabular}{|l|} 
Contagion/ \\
interspersion
\end{tabular} & $\begin{array}{c}\text { Interspersion and } \\
\text { juxtaposition } \\
\text { index }\end{array}$ & $|\mathrm{J}|$ & $\begin{array}{l}\text { Community dynamics, } \\
\text { persistence and } \\
\text { resilience of } \\
\text { communities }\end{array}$ & $\begin{array}{c}\text { Distribution of } \\
\text { riparian patches, i.e. } \\
\text { inner allocation of } \\
\text { different patches } \\
\text { (trees, shrubs, } \\
\text { herbaceous) }\end{array}$ \\
\hline
\end{tabular}

Whereas the evaluation of the structure of riparian vegetation benefits from a large-scale approach (river segments, catchments) - landscape level - the analysis of plant assemblages are usually treated as a small-scale issue (river reach, habitats) - local level (Franklin, 1993; Nakamura et al., 2005). Remote sensing data and geographic information systems (GIS) are used at the landscape level approach, whereas for the local scale approach, field surveys and data collection in-situ are usually necessary.

Though the spatial patterns can be assessed at a small-scale level, and species composition is beginning to be studied at a large scale, more frequently than desired, these two approaches have been addressed separately. For riparian restoration purposes, there is still a need to develop successful methodologies to identify areas to restore, to characterize previous ecological condition of riparian zones and to monitor and evaluate the success of the restoration efforts. The priorization of areas in potential need to enhance, preserve or restore is fundamental since economic resources are limited and frequently areas to manage are large and are difficult of access. 
TOOLS \& DATA

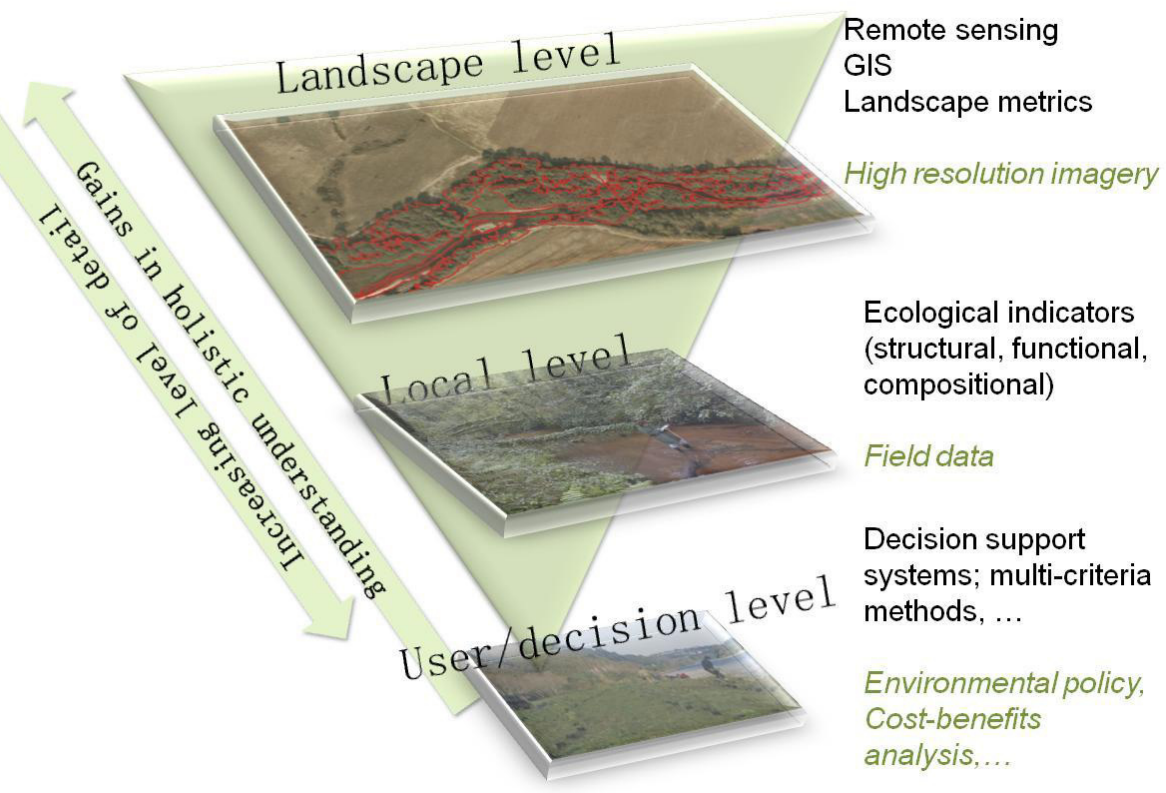

\section{Figure 1}

Illustration of the conceptual basis of the methodological approach, showing the material and general methods of each component.

\section{Figure 1}

Illustration des bases conceptuelles de la méthodologie, présentant les méthodes pour chaque niveau d'étude.

Information regarding the composition of riparian plant assemblages, species origin (alien, native, endemic), species cover and other plant attributes are also essential to make a more detailed diagnostic of the condition of the riparian vegetation ecosystem. This information has to be collected in loco in the field, usually using river reaches as sampling units, with an adequate length variable with the sampling purposes.

The data collected in field can be summarized in multimetric indices, also called biological integrity indices, IBI (Karr, 1981) that classify an ecosystem according to its deviation from a desired near-natural ecological condition. This condition often termed reference condition means that no or only minimal anthropogenic stresses can be observed, and it is widely used in ecological studies, monitoring programmes and in legislative tools such as the Water Framework Directive, WFD (2000/60/EC; European Council, 2000). A metric that composed IBI is considered a measurable parameter of the biological system that changes in value with human pressure (Karr and Chu, 1999). Examples of plant-based IBI that use riparian vegetation include the index of plant community integrity (DeKeyser et al., 2003), the plant index of biotic integrity (Simon et al., 2001; Rothrock et al., 2008) for US wetlands and lakes and the riparian vegetation index (Aguiar et al., 2009) for lberian streams, amongst others.

In the present work, we propose a method for the integration of the information collected at landscape and local scale levels in order to gain a holistic understanding of the riparian vegetation ecosystem and collect benefits from low-cost and less time-consuming techniques (Figure 1). Advantages and limitations of this approach are hereby discussed and potential applications are addressed. 


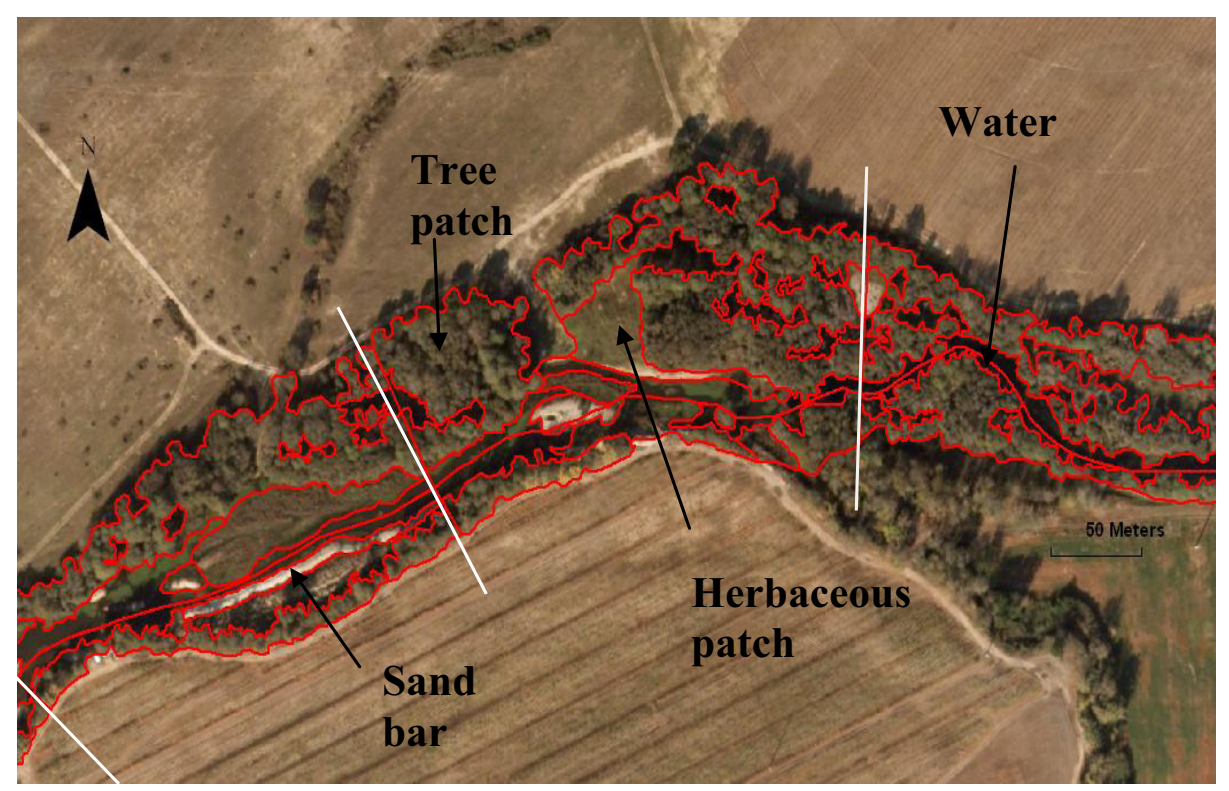

Figure 2

Limits of the sampling units (white lines) and of the riparian vegetation patches (red lines).

Figure 2

Limite des zones d'échantillonnage (lignes blanches) et des taches de végétation rivulaire (lignes rouges).

\section{METHODS}

We propose three main steps for guiding ecological restoration and assessing the ecological condition of riparian vegetation in Mediterranean rivers.

\section{$>$ LANDSCAPE LEVEL}

The methodological procedure is based on the previous study in Mediterranean rivers of Iberia (tributaries of river Tagus) made by Fernandes et al. (2011). The study area is divided in sampling units of $250 \mathrm{~m}$ long river reaches, within which riparian patches of tree and shrubs are delineated manually using geographic information systems, as well as the herbaceous vegetation shaded areas within the riparian zone (Figure 2). These riparian patches are homogeneous areas of vegetation that can be visually distinguished from the adjoining ones by their color, grain and other textural features. Landscape metrics of each sampling unit are calculated using the Patch Analyst (Vector format) for ArcGIS v9. Spearman Rank correlations $(R)$ were initially used to evaluate the collinearity between the numerous landscape metrics available in the software. The correlated metrics $(|R|>0.8 ; p<0.01)$ were eliminated to avoid redundancy in the data. Eight landscape metrics from five categories were selected, namely: (i) area/density: number of patches (NP), mean patch size (MPS), patch size coefficient variation (PSCV); (ii) shape: mean shape index (MSI), (iii) area/edge: mean fractal dimension index (MPFD); (iv) isolation/proximity: mean proximity index (MPI), mean nearest-neighbor distance (MNND) and (v) contagio/interspection: interspection and juxtaposition index (IJI).

The information provided by the landscape metrics is analyzed and interpreted in order to assess the spatial patterns of the riparian woods. In general, a riparian zone in bad ecological condition (i.e. an impaired ecosystem) for Iberian Mediterranean streams has small riparian vegetation patches with less complex shapes, and also more homogeneous and isolated patches with low interspection (Fernandes et al., 2011). 
(a)

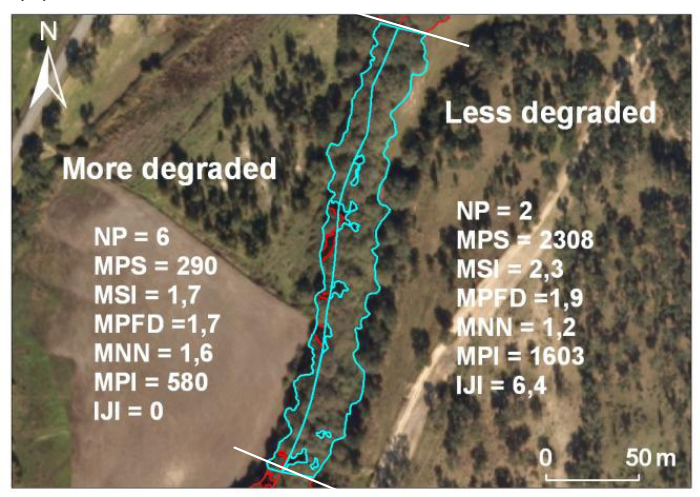

(b)

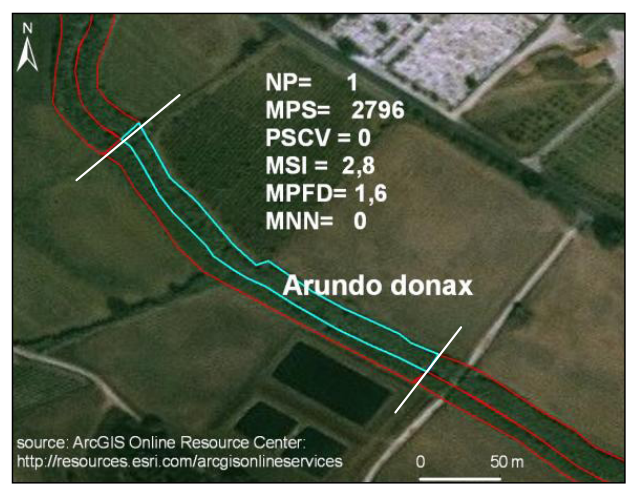

\section{Figure 3}

Illustration and values of the landscape metrics for: (a) two sampling units (one for each river margin) at river Chouto, tributary of river Tagus, Portugal and (b) one sampling unit at River Aveiras, Central-West Portugal, with monotypic stands of giant reed (Arundo donax). See Table I for landscape metrics designations. Length of the sampling units (white lines), sampling unit boundaries (blue lines), and riparian patches (red lines).

\section{Figure 3}

Illustration et valeur des métriques paysagères pour: (a) deux unités d'échantillonnage (une par berge) sur la rivière Chouto, affluent du Tage, Portugal et (b) une seule unité d'échantillonnage sur la rivière Aveiras, Centre-Ouest du Portugal, avec les stations monospécifiques de canne de Provence (Arundo donax). Voir le Tableau I pour les acronymes des métriques paysagères. Longueur des unités d'échantillonnage (lignes blanches), Limite des unités d'échantillonnage (lignes bleues) et taches de végétation rivulaire (lignes rouges).

In Figure 3a we present a comparison of the landscape metric values of two sampling units of a river stretch with different spatial patterns. We observed a low number of much smaller riparian tree patches (number of patches/mean patch size), with less jagged shapes (mean shape index), and a low interspersion of the patch distribution (interspection and juxtaposition index) near to agricultural areas than with agroforestry adjacent lands. On the other hand, highly impaired riparian zones, such as those invaded by alien species (e.g. Arundo donax L., giant reed) can have very different values of the landscape metrics and a completely diverse spatial configuration of riparian patches (Figure 3b). Since the giant reed forms dense monotypic and elongated patches, we expect higher values of mean shape index, and lower number of patches (one riparian patch per sampling unit) than in a riparian zone composed by native woody species.

Landscape metrics can be easily mapped in GIS platform to visualize riparian stretches, in order to prioritize the areas to restore, enhance or protect. We propose the definition of five quality classes for each one of the landscape metrics to allow the perception of these areas, using the natural Breaks' methodology (Jenks, 1967). Natural Breaks is a criteria of classification that minimize the sum of standard deviation intraclass and maximize the sum of the differences between classes. High spatial resolution imagery, such as airborne digital images RGB-NIR with no less than $0.5 \times 0.5 \mathrm{~m}$ is recommended for two reasons: first, the riparian zones have frequently a small width and this type of images allow the clear discrimination of riparian vegetation from the adjacent lands, and second, this resolution is necessary to capture the detailed configuration of the riparian patches. Radiometric resolution near eight bits (0-255) is the minimum required for the perception of the grey levels that allow the distinction between trees, shrubs and herbaceous vegetation. Concerning to the spectral resolution, three channels in the visible region are sufficient for the visual identification of the riparian vegetation strata, so-called "true color" images. 


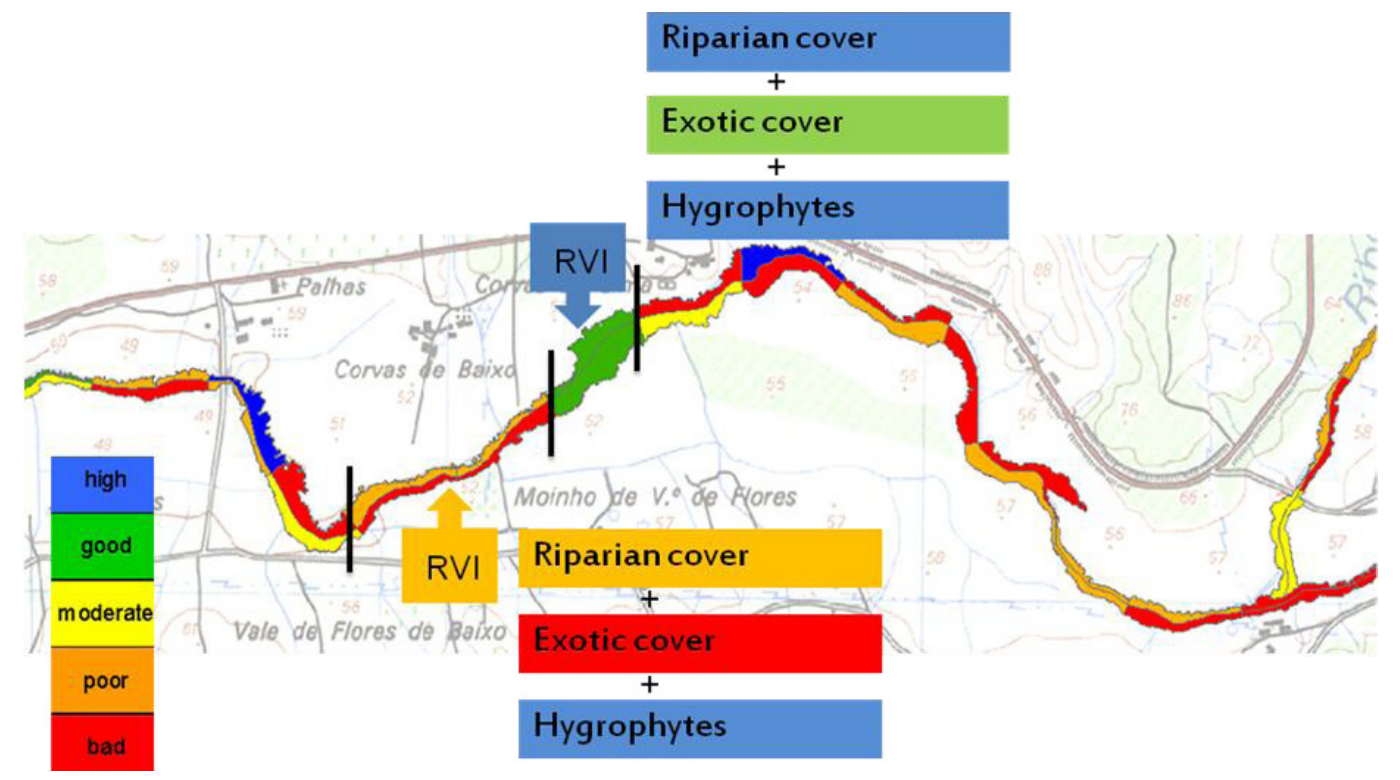

\section{Figure 4}

Illustrative results for the riparian vegetation index (RVI) values at a segment of Ribeira de Muge, tributary of Tagus river, Portugal, and of the mean patch size (filled polygons along the river stretch). Colors indicate the final classification of the studied vegetation attributes.

\section{Figure 4}

Résultats illustrant les valeurs de l'indice de végétation rivulaire $(R V I)$ sur une portion de la rivière de Muge, affluent du Tage, Portugal, ainsi que les tailles moyennes des taches de végétation rivulaire (polygones colorés le long des secteurs de rivière). Les couleurs indiquent la classification finale des attributs de la végétation étudiée.

\section{$>$ LOCAL LEVEL}

In the previous subsection, we proposed the use of landscape metrics to characterize the ecological status of riparian vegetation and to detect target areas to restore. The local level approaches bring in the field data and the application of a plant-based biotic integrity index to the areas that were remotely identified. The biotic integrity indices are multimetric indices that use structural, functional and compositional features of the riparian vegetation to measure the deviation of a given riparian site from the reference condition.

We suggest the use of the Riparian vegetation index (RVl; Aguiar et al., 2009) for Portuguese rivers and other rivers of Mediterranean Iberia. However, other indices can be chosen to assess local features of vegetation for other regions, such as the riparian quality index (González-del-Tánago and García-Jalón, 2006), and the plant index of biotic integrity (Simon et al., 2001; Rothrock et al., 2008). The RVI is a multimetric index, based on compositional metrics (e.g. cover and number of alien and endemic species) and functional metrics associated with life cycle and reproduction (e.g. numbers of perennial species), and with trophic status (e.g. proportion of nitrophyllous species) (Table II).

For the development of the index, Aguiar et al. (2009) analysed 33 potential metrics out of a set of 300 vegetation attributes that could reflect the ecosystem processes and functions at different levels, and respond to various types of human pressures, mainly to the nutritive enrichment, hydromorphological alterations, such as physical habitat alterations and channelization, and use of adjacent lands. The selection of metrics to integrate the index involved four sequential steps: (i) response to human pressures, (ii) accordance between expected and observed response to pressures, (iii) the ability to provide unique information (i.e. non-redundancy), and (iv) field assessment and calculation' efforts. The selected metrics were transformed to dimensionless numbers for aggregation into the index. For each metric, 


\section{Table II}

Metrics of the riparian vegetation index (RVI) for North and South regions and scoring criteria used to rescale the metric values. Median of reference sites and ecological quality class boundaries using the ecological quality ratio values (for more details see Aguiar et al., 2009). H-High; G-Good; M-Moderate; P-Poor; B-Bad.

\section{Tableau 2}

Descripteurs de l'indice de végétation rivulaire $(R V I)$ pour les régions nord et sud portugaises et les critères de normalisation des métriques. Valeurs médianes des sites de reférence et limites des classes de qualité écologique selon les valeurs des ratio de qualité écologique (pour ce calcul de ratio et plus de détails voir Aguiar et al., 2009). H - Élevé ; G - Bon ; M - Modéré ; P - Faible ; B - Mauvais.

\begin{tabular}{|c|c|c|c|c|c|c|c|}
\hline \multirow{2}{*}{\multicolumn{2}{|c|}{ METRICS }} & \multicolumn{3}{|c|}{ RVI north } & \multicolumn{3}{|c|}{ RVI south } \\
\hline & & $\begin{array}{c}5 \\
\text { (Good) }\end{array}$ & $\begin{array}{c}3 \\
\text { (Moderate) }\end{array}$ & $\begin{array}{c}1 \\
(\mathrm{Bad})\end{array}$ & $\begin{array}{c}5 \\
(\text { Good) }\end{array}$ & $\begin{array}{c}3 \\
\text { (Moderate) }\end{array}$ & $\begin{array}{c}1 \\
(\mathrm{Bad})\end{array}$ \\
\hline \multicolumn{2}{|l|}{ Total richness (n.) } & & & & $\geq 62$ & $55.5-62$ & $<55.5$ \\
\hline \multicolumn{2}{|c|}{ Proportion of endemic species (\%) } & $\geq 5.2$ & $3.2-5.2$ & $<3.2$ & $\geq 1.9$ & $0.1-1.9$ & $<0.1$ \\
\hline \multicolumn{2}{|c|}{ Proportion of hygrophytes (\%) } & $\geq 59.6$ & $0.5-59.6$ & $<0.5$ & $\geq 41.8$ & $0.5-41.8$ & $<0.5$ \\
\hline \multicolumn{2}{|l|}{$\begin{array}{l}\text { Proportion of acidophyllous } \\
\text { species (\%) }\end{array}$} & $\geq 12.7$ & $8.7-12.7$ & $<8.7$ & $\geq 5.7$ & $2.8-5.7$ & $<2.8$ \\
\hline \multicolumn{2}{|c|}{ Proportion of perennial species (\%) } & $\geq 84$ & $76.5-84$ & $<76.5$ & & & \\
\hline \multicolumn{2}{|c|}{$\begin{array}{l}\text { Cover of Carex elata ssp. reuterana } \\
(\%)\end{array}$} & $\geq 0.7$ & $0.1-0.7$ & $<0.1$ & & & \\
\hline \multicolumn{2}{|c|}{ Proportion of alien species (\%) } & $\leq 4.8$ & $4.8-8$ & $>8$ & $\leq 3.7$ & $3.7-7.9$ & $>7.9$ \\
\hline \multicolumn{2}{|l|}{ Cover of alien species (\%) } & $\leq 0.5$ & $0.5-2.8$ & $>2.8$ & $\leq 0.5$ & $0.5-4.8$ & $>4.8$ \\
\hline \multicolumn{2}{|c|}{$\begin{array}{l}\text { Proportion of nitrophyllous species } \\
\text { (\%) }\end{array}$} & & & & $\leq 3.9$ & $3.9-6.5$ & $>6.5$ \\
\hline \multicolumn{2}{|c|}{$\begin{array}{l}\text { Richness in bulbous + tuberous } \\
\text { species ( } \mathrm{n} \text {.) }\end{array}$} & & & & $\leq 4$ & $4-15.5$ & $>15.5$ \\
\hline \multicolumn{2}{|c|}{ Proportion of ruderal species (\%) } & $\leq 8.3$ & $8.3-11.4$ & $>11.4$ & & & \\
\hline \multicolumn{2}{|l|}{ Weighted riparian cover } & $\geq 3.3$ & $0.7-3.3$ & $<0.7$ & $\geq 6.5$ & $0.6-6.5$ & $<0.6$ \\
\hline \multicolumn{2}{|l|}{$\begin{array}{l}\text { Cover of Erica arborea + } \\
\text { Frangula alnus (\%) }\end{array}$} & $\geq 0.4$ & $0.1-0.4$ & $<0.1$ & & & \\
\hline \multicolumn{2}{|l|}{ Range of variation } & \multicolumn{3}{|c|}{$10-50$} & \multicolumn{3}{|c|}{$9-45$} \\
\hline \multicolumn{2}{|l|}{ Median of reference sites } & \multicolumn{3}{|c|}{30} & \multicolumn{3}{|c|}{24} \\
\hline \multirow{4}{*}{$\begin{array}{l}\text { Boundaries of ecological } \\
\text { quality classes } \\
\text { (in ecological quality ratio } \\
\text { values) }\end{array}$} & $\mathrm{H} / \mathrm{G}$ & \multicolumn{3}{|c|}{0.67} & \multicolumn{3}{|c|}{0.75} \\
\hline & $\mathrm{G} / \mathrm{M}$ & \multicolumn{3}{|c|}{0.50} & \multicolumn{3}{|c|}{0.56} \\
\hline & $\mathrm{M} / \mathrm{B}$ & \multicolumn{3}{|c|}{0.33} & \multicolumn{3}{|c|}{0.37} \\
\hline & $\mathrm{B} / \mathrm{P}$ & \multicolumn{3}{|c|}{0.16} & \multicolumn{3}{|c|}{0.19} \\
\hline
\end{tabular}

three scores were assigned: 1 - poor, 3 - fair, and 5 - good quality, calibrated by the reference condition approach (Hering et al., 2006). Reference sites were pre-selected following personal knowledge and a preliminary screening using digital databases from the INAG and the Portuguese water resources information system (http://www.snirh.pt). Then, a classification of disturbance was assigned to each potential reference site, according to Pont et al. (2006). The reference sites were chosen to reflect totally or nearly undisturbed conditions for (i) the hydromorphological condition, (ii) general physico-chemical features, (iii) the riparian zone, and presenting (iv) minimal land-use in the drainage basin.

The good-fair boundary was limited by the median of reference sites, and the poor-fair boundary by the median of the non-reference sites (i.e. impacted sites). The RVI for a site was obtained by the sum of the quality scores of all metrics, subtracted by the total number of 
metrics. RVI values were transformed into ecological quality ratio (EQR) values. Five ecological quality classes were assigned: high (best of five classes), good, moderate, poor and bad. The high/good boundary was established using the 25th percentile of the reference sites. The four remaining classes were obtained by dividing the interval limited by the high/good boundary and the lower extremity of the gradient equally, in accord with Wallin et al. (2003). The index was developed for small $\left(<100 \mathrm{~km}^{2}\right.$ of drainage basin) and mediumsized rivers (100-1000 $\mathrm{km}^{2}$ of drainage basin) and originally contemplated diverse configurations for each of the nine river types of Portugal. The Portuguese river typology was developed for the implementation of the WFD, and can be consulted in http://dqa.inag.pt/dqa2002/port/implementa/Manuais.html. River types were defined by abiotic settings (climatic, altitude and area of drainage basin) and with the differences in species composition of four components of the fluvial ecosystem (fish, diatoms, macrophytes and macro invertebrates) (INAG IP, 2008a). The index presented more consistent responses to human pressures when the various river types were grouped (Aguiar et al., 2009). The classification was performed using only macrophyte data, and two regions were obtained north and south. The resulting RVI score lies in the range 0-40 for the North region and 0-36 for the South region (the lower the score, the poorer ecological condition). Ranges of metrics and quality class values can be found in Table II. Differences between these two regions were translated in various vegetation responses to human pressure, and thus differences in the component metrics and in their scoring.

For the calculation of RVI, the field sampling based on the European standard EN14184:2003 "water quality - guidance for the surveying of aquatic macrophytes in running waters", approved by the Comité Européen de Normalization is recommended. Spring-early Summer is considered the best period for floristic sampling in Mediterranean rivers. Since all species present in the river and riparian zone are needed to assess the overall alteration of the fluvial ecosystem, all plant species found in water and banks need to be recorded. So, the floristic sampling should include besides the macrophytes, terrestrial species and riparian woody species, such as trees, shrubs and woody climbers. A macrophyte is defined as a plant visible to the naked eye and nearly identifiable when observed, growing in or near water. This definition includes higher aquatic plants, vascular cryptograms, bryophytes, and macroalgae. Surveys are made in $100 \mathrm{~m}$ long river stretches, by wading upstream in a zig-zag manner across the channel or by walking in banks. Then a downstream re-wade in the river stretch is done to ensure that all species are recorded, and to confirm the species abundance attributed in the first assessment. Percentage cover of each species is estimated for the sampled area. Details on sampling procedures can be found in INAG IP (2008b), and of the RVI in Aguiar et al. $(2009,2011)$.

\section{$>$ INTEGRATIVE APPROACH}

In implementing this approach, we considered three major steps: (i) the identification of priority areas to restore (landscape level), (ii) the identification of the magnitude and type of degradation (local level), and (iii) interpretation and translation of the information to be used by end-users (decision level). The results of the classification (landscape and local level) can be both georeferenced and mapped on a GIS platform (Figure 4). River managers can visualize not only the condition of the riparian zones but also the type the degradation, eg. invasive species, lack of longitudinal continuity, low riparian width. However, no clear inferences are made regarding the causes of the alteration of the condition of the riparian vegetation. That is, neither the landscape metrics nor the metrics that compose the RVI give a precise cause for the degradation of the riparian vegetation, but do assess the effects of pressures.

\section{DISCUSSION}

A preliminary classification of the ecological condition of the riparian zone can be obtained through the interpretation of the landscape metrics. The joint combination of the landscape 
metrics from various categories is recommended. The detailed identification of spatial patterns of riparian vegetation can be recognized through the combination of area/density (number of patches, mean patch size) and isolation/proximity metrics (mean proximity index, mean nearest-neighbor distance), and other metrics related with ecological fluxes and species dynamics (mean shape index, mean fractal dimension index). However, a quick identification of fragmented areas can be obtained using a combination of the mean nearestneighbor distance with the mean patch size, or even using a single metric - the mean proximity index, with a certain threshold level.

At the local level, the RVI can classify a given location in bad ecological quality status, but for different reasons. For instance, the metrics that compose the index can point to high cover and richness of alien plant species, and low numbers of endemics, whereas in another situation the structural metrics as the riparian cover can be those with a low ranking. This information is important as a guideline for river managers. The former situation points to the need to restore the composition of the riparian communities, by removing or lowering the cover of alien species and mitigating the native species communities, whereas the later points to a structural restoration by increasing the riparian width, and restoring the longitudinal connectivity of riparian woods.

Major advantages of this integrative approach, when compared with the field-centered classical approaches are the preliminary identification of areas to restore, using less-time consuming techniques, lowering the costs and human resources. Many studies use only biological information collected at river segment or at the habitat level, lacking in the perception of the riparian condition upstream/downstream of the studied area. If the goal of the restoration has been defined for a well-delimitated region, this option is surely the best, since it characterizes in detail the area under study. On the other hand, the approach hereby presented is better for studies in large or unknown areas, since it identifies potential weaknesses in the ecological condition of riparian forests.

Some authors have used land cover predictors (agriculture, impervious areas of surroundings) obtained from remote sensing techniques together with biological indices to assess the ecological status of rivers and water quality (Goetz and Fiske, 2008) and to quantify the nature and magnitude of riparian landscape structural changes within catchments (Apan et al., 2002; Tormos et al., 2011). Others have used hierarchical approaches at the regional, catchment and local scales to make informed decisions in restoration planning and management of riparian areas (Nakamura et al., 2005; Lake et al., 2007).

However, we must be aware that various limitations exist. One of the most important concerns is the existence of geomomorphological constraints that reduce the complexity of the riparian zones and mimic patterns of fragmentation and patchiness. In fact, small mountainous rivers near to the source, have frequently bedrock and boulders as dominant substrate, and can only support shrub and herbaceous vegetation. Thus, the interpretation of the landscape metrics must take into account the position of the surveyed location in the longitudinal river gradient and the geomorphological background. Another problem is the temporal window that may exist between the date of the digital imagery and the date of field survey and could led to outdated information. Caution must also be taken when comparing metric values from imagery with different spatial resolutions or characteristics (Mas et al., 2010).

We have also to keep in mind that the interpretation of the values of the landscape metrics cannot be applied to other regions than the studied basin (river Tagus, Portugal) without a prior analysis of well-preserved riparian zones, i.e. different biogeographical regions need a calibration of the reference condition. Moreover, in complement of a plant-based index, other information on the hydromorphological condition and of the main human pressures (e.g. vegetation removal, dams, weirs) on river and river surroundings (e.g. industrial areas, intensive agriculture) is important for a sustainable restoration of the riparian vegetation.

We conclude along with other top-down approaches (e.g. Nakamura et al., 2005; Lake et al., 2007; Goetz and Fiske, 2008) that they have a important twofold benefit: (i) the gain on holistic understanding of the ecosystems and ecological support for managerial and planning decisions, and (ii) the reduction of the costs of management and restoration planning. 


\section{ACKNOWLEDGMENTS}

This study received backing from the projects RIPIDURABLE "Gestion Durable de Ripisylves" (INTERREG III-C Sul - 3S0125I), RICOVER "River Ricovery in the SW Europe" (Interreg IVB SOE1/P2/P248) and from the Forest Research Centre, CEF through FEDER/POCI 2010. Francisca C. Aguiar was supported by post-doc grant (SFRH/BPD/29333/2006), from the Foundation for Science and Technology, Portugal, and Maria Rosário Fernandes by a doctoral grant (SFRH/BD/44707/2008) from the same institution. We acknowledge the Instituto Geográfico Português (IGP), which provided the airborne digital images through the FIGEE program.

\section{REFERENCES}

Aguiar F.C. and Ferreira M.T., 2005. Human-disturbed landscapes: effects on composition and integrity of riparian woody vegetation in Tagus river basin, Portugal. Environ. Cons., 32, 30-41.

Aguiar F.C., Moreira I. and Ferreira M.T., 2001. Exotic and native vegetation establishment following channelization of a western Iberian river. Regul. Rivers Res. Manage., 17, 509-526.

Aguiar F.C., Ferreira M.T., Albuquerque A., Rodríguez-González P. and Segurado P., 2009. Structural and functional responses of riparian vegetation to human disturbance: performance and spatialscale dependence. Fund. App. Lim., 175, 249-267.

Aguiar F.C., Feio M.J. and Ferreira M.T., 2011. Choosing the best method for stream bioassessment using macrophyte communities: indices and predictive models. Ecological Indicators, 11, 379-388.

Allan J.D., 2004. Landscapes and Riverscapes: the influence of land use on stream ecosystems. Ann. Rev. Ecol. Syst., 35, 257-284.

Apan A.A., Raine S.R. and Paterson M.S., 2002. Mapping an analysis of changes in the riparian landscape structure of Lockyer Valley catchment Queensland, Australia. Landscape Urban Plan., $59,43-57$.

Congalton R.G., Birch K., Jones R. and Schriever J., 2002. Evaluating remotely sensed techniques for mapping riparian vegetation. Comput. Electron. Agr., 37, 113-126.

DeKeyser E.S., Kirby D.R. and EII M.J., 2003. An index of plant community integrity: development of the methodology for assessing prairie wetland plant communities. Ecological Indicators, 3, 119-133.

European Council, 2000. Directive 2000/60/EC of the European Parliament and of the Council of 23 October 2000 establishing a framework for Community action in the field of water policy. Official Journal, L327, 1-73.

Fernandes M.R., Aguiar F.C. and Ferreira M.T., 2011. Assessing riparian vegetation structure and the influence of land-use using landscape metrics and geostatistical tools. Landscape Urban Plan., 99, 166-177.

Ferreira M.T., Aguiar F.C. and Nogueira C., 2005. Changes of riparian woods over space and time: influence of environment and land use. For. Ecol. Manage., 212, 145-159.

Forman R.T.T., 1995. Land Mosaics: The Ecology of Landscapes and Regions, Cambridge, Cambridge University Press.

Forman R.T.T. and Godron M., 1981. Patches and structural components for landscape ecology. BioScience, 31, 733-740.

Franklin J.F., 1993. Preserving biodiversity: species, ecosystems, or landscape? Ecol. Appl., 3, 202-205.

Goetz S. and Fiske G., 2008. Linking the diversity and abundance of stream biota to landscapes in the mid-Atlantic USA. Rem. Sens. Environ., 112, 4075-4085.

González-del-Tánago M. and Garcia-Jalón D., 2006. Attributes for assessing the environmental quality of riparian zones. Limnetica, 25, 389-402.

Hering D., Feld C.K., Moog O. and Ofenböck T., 2006. Cook book for the development of a multimetric index for biological condition of aquatic ecosystems: Experiences from the European AQEM and STAR projects and related initiatives. Hydrobiologia, 566, 311-324.

Hooke J.M., 2006. Human impacts on fluvial systems in the Mediterranean region. Geomorphology, 79, 311-335.

Hyatt T.L., Waldo T.Z. and Beechie T.J., 2004. A watershed scale assessment of riparian forests with implications for restoration. Restor. Ecol., 12, 175-183. 
INAG IP, 2008a. Tipologia de Rios em Portugal Continental no âmbito da Implementação da Directiva Quadro da Água, I. Caracterização abiótica, Ministério do Ambiente, do Ordenamento do Território e do Desenvolvimento Regional, Instituto da Água IP, Lisboa, 32 p.

INAG IP, 2008b. Manual para a avaliação biológica da qualidade da água em sistemas fluviais segundo a Directiva Quadro da Água, Protocolo de amostragem e análise para os macrófitos, Ministério do Ambiente, do Ordenamento do Território e do Desenvolvimento Regional, Instituto da Água IP, Lisboa, $18 \mathrm{p}$.

Ivits E., Cherlet M., Mehl W. and Sommer S., 2009. Estimating the ecological status and change of riparian zones in Andalusia assessed by multi-temporal AVHHR datasets. Ecological Indicators, 9, 422-431.

Jenks G.F., 1967. The data model concept in statistical mapping. International Yearbook of Cartography, 7, 186-190.

Johansen K. and Phinn S., 2006. Mapping structural parameters and species composition of riparian vegetation using IKONOS and Landsat ETM+ Data in Australian Tropical Savannahs. Photogramm. Eng. Rem. S., 72, 71-80.

Johansen K., Coops N.C., Gergel S.E. and Stange Y., 2007. Application of high spatialresolution satellite imagery for riparian and forest ecosystem classification. Rem. Sens. Environ., 110, $29-44$.

Karr J.R., 1981. Assessment of biotic integrity using fish communities. Fisheries, 6, 1-27.

Karr J.R. and Chu E.W., 1999. Restoring Life in Running Waters: Better Biological Monitoring, Inland Press, Washington DC, US.

Lake P.S., Bond N. and Reich P., 2007. Linking ecological theory with stream restoration. Freshw. Biol., $52,597-602$.

Mas J.-F., Gao Y. and Pacheco J.A.N., 2010. Sensitivity of landscape pattern metrics to classification approaches. For. Ecol. Manage., 259, 1215-1224.

Moser T.J., Lindeman D.R., Wigington P.J. Schuft, M. and Van Sickle J., 2000. Methods for multi-spatial scale characterization riparian corridors, U.S. Environmental Protection Agency, Office of Research and Development, National Health and Environmental Effects Laboratory, 7 p.

Naiman R.J. and Décamps H., 1997. The ecology of interfaces: riparian zones. Annu. Ver. Ecol. Syst., 28, 621-658.

Naiman R.J., Décamps H. and McClain M., 2005. Riparia. Ecology, Conservation, and Management of Streamside Communities, Elsevier Academic Press, San Diego- USA, 430 p.

Nakamura F., Inahara S. and Kaneko M., 2005. A hierarchical approach to ecosystem assessment of restoration planning at regional, catchment and local scales in Japan. Landscape Ecol. Eng., 1, 43-52.

Pont D., Hugueny B., Beier U., Goffaux D., Melcher A., Noble R., Rogers C., Roset N. and Schmutz S., 2006. Assessing river biotic condition at a continental scale: a European approach using functional metrics and fish assemblages. J. Appl. Ecol., 43, 70-80.

Rothrock P.E., Simon T.P. and Stewart P.M., 2008. Development, calibration, and validation of a littoral zone plant index of biotic integrity (PIBI) for lacustrine wetlands. Ecological Indicators, 8, 79-88.

Schuft M.J., Moser T.J., Wigington P.J., Stevens D.L., McAllister L.S., Chapman S.S. and Ernst T.L., 1999. Development of landscape metrics for characterizing riparian-stream networks. Photogramm. Eng. Rem. S., 65, 1157-1167.

Simon T.P., Stewart P.M. and Rothrock P.E., 2001. Development of multimetric indices of biotic integrity for riverine and palustrine wetland plant communities along Southern Lake Michigan. J. Aquat. Ecosyst. Health Manage., 4, 293-309.

Tormos T., Kosuth P., Durrieu S. Villeneuve B. and Wasson J.G., 2011. Improving the quantification of land cover pressure on stream ecological status at the riparian scale using high spatial resolution imagery. Phys. Chem. Earth Parts A/B/C, 36, 549-559.

von Schiller D., Martí E., Riera J.L., Ribot M., Marks J.C. and Sabater F., 2008. Influence of land use on stream ecosystem function in a Mediterranean catchment. Freshw. Biol., 53, 2600-2612.

Wallin M., Wiederholm T. and Johnson K.R., 2003. REFCOND. Development of a protocol for identification of reference conditions, and boundaries between high, good and moderate status in lakes and watercourses, Working Group 2.3, EU Common Implementation Strategy (CIS) for the Water Framework Directive, 7th version.

Ward T.A., Tate K.W. and Atwill E.R., 2003. Visual assessment of riparian health. Rangeland 546 Monitoring Series, Publication 8089, University of California, $23 \mathrm{p}$.

Yang X., 2007. Integrated of remote sensing and geographic information systems in riparian vegetation delineation and mapping. Int. J. Remote Sens., 28, 353-370. 